\title{
Alkaloids of Peganum harmala L. and their Pharmacological Activity
}

\author{
Aidos Doskaliyev $^{1,2} \mathbb{D}$, R. B. Seidakhmetova ${ }^{1}$, D. S. Tutai ${ }^{1}$, Kristina Goldaeva ${ }^{1}$ D, V. K. Surov ${ }^{2}$, S. M. Adekenov ${ }^{1}$ \\ ${ }^{1}$ JSC "International Research and Production Holding Phytochemistry", Karaganda, Republic of Kazakhstan; ${ }^{2}$ JSC "National \\ Centre for Neurosurgery", Nur-Sultan, Republic of Kazakhstan
}

Edited by: Sinisa Stojanos Citation: Doskaliev A, Seidakhmetova RB, Tutai DS, Goldaeva K, Surov VK, Adekenov SM. Alkaloids of Peganum harmala L. and their Pharmacological Activity. Open Access Maced J Med Sci. 2021 Sep 08; 9(A):766-775 Keywords: Harmine hydrochloride; Neurotropic Antidepressant; Antiparkinsonian; Antihypoxic Cioavaliability "Cormespondence. R. B. Seidakhmetova, JSC "International Research and Production Holding Gazaliev sre. 4, 100009. E-mail: info@phyto.k Revised: 29-Jul-202 Accepted: 28-Aug-202
Copyright: $\odot 2021$ Aidos Doskaliyev, R. B. Seidakhmetova, D. S. Tutai, Kristina Goldaeva, V. K. Surov, S. M. Adekenov Funding: The work was carried out under the gran poject AP08052389 "Development of a new neurotropic drug: pharmacological and clinical studies," funded by the Science Committee of the Ministry of Education an Science of the Republic of Kazakhstan. competing interest exists
Open Access: This is an open-access article distributed competing interest exists
Open Access: This is an open-access article distributed under the terms of the Creative Commons Attribution-
NonCommercial 4.0 International License (CC BY-NC 4.0)

\section{Introduction}

Peganum harmala L. (P. harmala L. - Figure 1) is a perennial herb of the Zygophyllaceae family, widespread in Central Asia, North Africa, and the Central East [1], [2] (Figure 1). This type of plant is found everywhere in Kazakhstan, excluding the highlands. During our expeditionary research, commercial stocks of $P$. harmala L. were revealed [3]. According to the results of the route reconnaissance survey of the Kurdai mountain range of the Zhambyl region, the Ordabasy district of the Turkestan region, and the Zhanakorgan district of the Kyzylorda region, the distribution and reserves of raw materials of $P$. harmala $\mathrm{L}$. were determined. On the territory of Ordabasynsky district north-west of the Zhambyl village, operational reserves of 18.6 tons in the calculation of dry raw materials and the volume of annual procurement of not more than 6.2 tons of dry raw materials were revealed. South-east of the Koltogan village, near the Bergen Isakhanov village, operational stock is 13.5 tons with annual procurement volume of no more than 4.5 tons of dry raw materials. Herbarium specimens are kept in the collections of JSC "International Research and Production Holding Phytochemistry."

$P$. harmala $L$. has been used for a long time in traditional medicine in Turkey, Iran, and China for the treatment of hypertension, lumbago, asthma, diabetes, various infections, and also as an antitumor, antiinfectious, and anti-inflammatory agent [4], [5]. In the Caucasus, it is sometimes used as a sleeping pill, like Indian hemp. In Azerbaijan, P. harmala L. is universally known as a medicinal plant.

In Tajikistan, paralytics are fumigated with this plant, and poultices for tumors are made from the leaves. Decoction of seeds together with flax or 


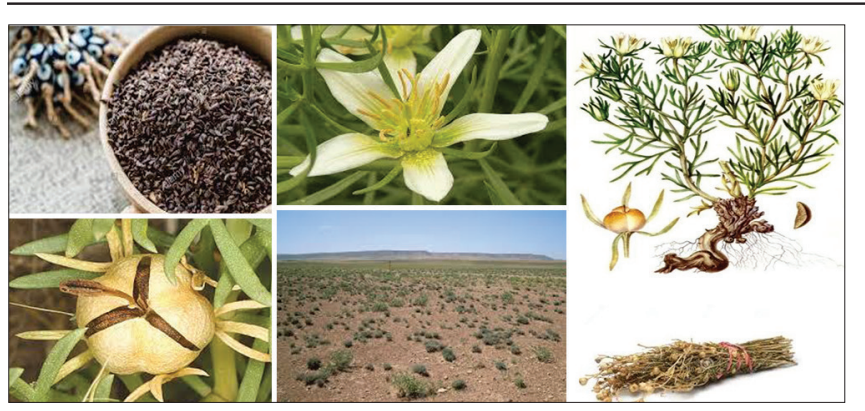

Figure 1: P. harmala L. and its alkaloid containing organs

sesame seeds treats asthma, shortness of breath, and rheumatism; used as a sedative, choleretic, diuretic, and diaphoretic. Experimental results indicate that extracts of $P$. harmala $\mathrm{L}$. are inhibitors of cholinesterase and monoamine oxidase and have antitumor, anticoagulant, hypotensive, antidiabetic, antibacterial, antiviral, antiinflammatory, and antiparasitic activities. Seeds exhibit hypothermic, antiplasmodic, cytotoxic, and vasorelaxant activities [6], [7]. As a result of pharmacological studies in recent years, antitumor, insecticidal, hypoglycemic, antidiabetic, hepatoprotective, analgesic, antibacterial, and fungicidal actions of individual organs of $P$. harmala $L$. and their extracts have been revealed [8], [9], [10], [11], [12] (Figure 2).

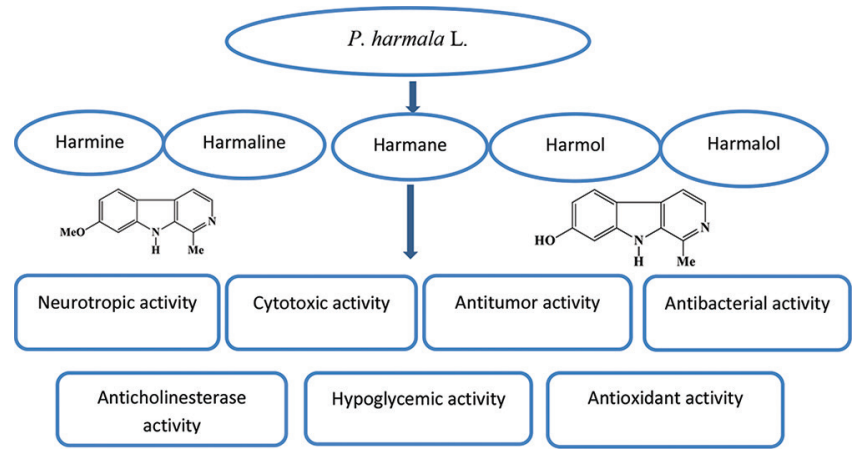

Figure 2: Alkaloids of P. harmala L. and their pharmacological actions

In $P$. harmala L., the content of alkaloids varies according to the vegetation phases of the plant: In the early growing season, the content of alkaloids in the aerial part is $2.17 \%$, in young roots $-3.32 \%$, in old roots - $1.68 \%$; during budding in the aerial part $-2-2.3 \%$; during the flowering period in the aerial part $-1.86-1.95 \%$; the beginning of fruiting $-1.3 \%$; mass fruiting $-0.69 \%$; end of the growing season, in the aerial part $-0.5 \%$, in the roots $-1.8 \%$, and seeds $-5 \%$.

All parts of $P$. harmala L. contain alkaloids, seeds, and roots are especially rich in them, and more than a quarter of them are harmine 1. The seeds of $P$. harmala $\mathrm{L}$. also contain harmaline 2 . It usually accounts for half to two-thirds of alkaloids in total. The roots contain only harmine 1; in flowers and stems - peganin 3; there was also found harmalol 4 and a number of other alkaloids.

Harmine 1 is found in plants $P$. harmala L. and Banisteia varieties, namely,Banisteia caapi L., Spruce,
Banisteia lutea L., and Banisteia metallicolor L. Harmine 1 was first isolated in the $19^{\text {th }}$ century from the seeds of $P$. harmala L. and Banisteriopsis caapi M., which are traditionally used in the Middle East, Central Asia, and the South of America [13], [14], [15].

Harmine hydrochloride 5 has a therapeutic effect in Parkinsonism after lethargic encephalitis and tremors. Peganin hydrochloride $\mathbf{6}$ is approved as an anticholinesterase agent [16]

\section{Alkaloids of $P$. harmala L. and their Pharmacological Activity}

Alkaloids, flavonoids, steroids, amino acids, anthraquinones and polysaccharides, and volatile oils were isolated from $P$. harmala $L$. and studied [17], [18], [19]. Among these compounds, alkaloids were the main components, the total content of which was $2-5 \%$. Alkaloids were found in the roots (up to $2 \%$ by weight) and seeds (4.3-5.6\% by weight) of the plant [20].

The pharmacologically active constituents of $P$. harmala $\mathrm{L}$. are alkaloids, found mainly in seeds and roots. At the same time, harmine 1, harmaline $\mathbf{2}$, harmalol $\mathbf{4}$, tetrahydroharmine $\mathbf{7}$, harmalicin $\mathbf{8}$, 3,4-dihydroharmane $\mathbf{9}$ and 7-hydroxy-3,4-dihydronorharmin-1-one 10, as well as tetracyclic lactams harmalanine 11 and harmalacidin 12 [14], [21], [22], $\beta$-carboline alkaloids were isolated from $P$. harmala $L$. and their structures were established.

Julius Fritzsche was the first to isolate a new alkaloid from $P$. harmala $L$. seed husks in 1848 and named harmine 1.A related harmaline was isolated from $P$. harmala $L$. and named by Friedemann Gebel in 1837. The pharmacology of harmine 1 was not studied in detail until 1895. Harmine 1 and harmaline 2 structures were established in 1927 by Hellmuth et al. [23].

The quinazoline alkaloids of $P$. harmala L. can be divided into two groups: Derivatives of 3,4-dihydroquinazoline (peganin 3, deoxypeganin 13, peganol 14 , peganidine 15 , and $4-(3 \mathrm{H})$-quinazolinone (vazicinone 16, deoxyvazicinone 17, and pegamin 18). Peganin 3 (0.04\%), deoxypeganin 13 (0.012\%), vazicinone $16(0.027 \%)$, and deoxyvazicinone $17(0.017 \%)$, along with harmine $1(1.23 \%)$, were isolated by us from $P$. harmala L. collected in Kurday district of Zhambyl region [24].

The pharmacological action of $P$. harmala $\mathrm{L}$. is associated with the presence in its composition of $\beta$-carboline alkaloids - harmine 1 and its analogs (Figure 2) [25], [26], [27]. The alkaloids of P. harmala L. exert psychoactive effect.

Harmine $\mathbf{1}$ is a hallucinogen, a stimulant of the central nervous system, a short-term inhibitor of 
<smiles>COc1ccc2c(c1)[nH]c1c(C)nccc12</smiles>

1

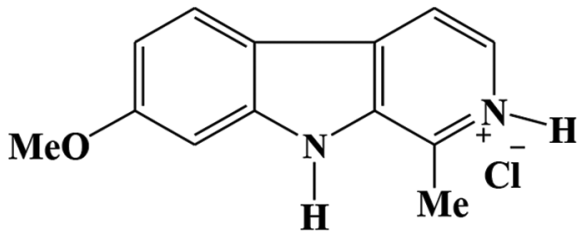

5<smiles>CC1NC=Cc2c1[nH]c1ccccc21</smiles>

9<smiles>c1ccc2c(c1)CN1CCCC1=N2</smiles><smiles>OC1c2ccccc2N=C2CCCN21</smiles>

14
13<smiles>[R20]Oc1ccc2c3c([nH]c2c1)C([Y])=NCC3</smiles>

2: $\mathbf{R}=\mathrm{CH}_{3}$;

4: $\mathbf{R}=\mathbf{H}$<smiles>O[C@H]1CCN2Cc3ccccc3NC12Cl</smiles>

6<smiles>O=C1NCCc2c1[nH]c1ccccc21</smiles>

10<smiles>O[C@@H]1CCN2Cc3ccccc3N=C12</smiles>

3<smiles>[Y1]C1NCCc2c1n([Y2])c1cc(OC)ccc21</smiles>

7: $\mathbf{R}^{1}=\mathbf{C H}_{3}, \mathbf{R}^{2}=\mathbf{H}$;

8: $\mathbf{R}^{1}=\mathbf{H}, \mathbf{R}^{2}=\mathbf{C H O}$<smiles></smiles>

11: $\mathbf{R}=\mathrm{CH}_{3}$;

12: $\mathbf{R}=\mathbf{H}$<smiles>CC(=O)CC1c2ccccc2N=C2[C@H](O)CCN21</smiles>

15<smiles>[R]C1CCn2c1nc1ccccc1c2=O</smiles>

16: $\mathrm{R}=\mathrm{OH}$; 17: $\mathbf{R}=\mathbf{H}$<smiles>O=c1[nH]c(CCCO)nc2ccccc12</smiles>

18 monoamine oxidase. In Germany, since 1927, the drug "Harmine," developed by Merck Company, has been actively used for the treatment of patients with post-encephalitic Parkinsonism and tremor paralysis. However, by the end of 1929, doctors realized the unrealistic expectations of the drug "Harmine" and emphasized in their presentations that the pharmacological effects of harmine were variable and shortlived [28]. At present, harmine was excluded from the nomenclature of drugs due to the appearance of more effective and safe MAO inhibitors [29].

Harmaline 2 acts as an acetylcholinesterase inhibitor and also stimulates the release of dopamine in the corpus striatum in rats at very high doses. Since harmaline is a reversible inhibitor of monoamine oxidase A, theoretically it can cause both serotonin syndrome and hypertensive crisis in combination with tyramine, serotonergic, catecholaminergic drugs, or prodrugs. Harmaline 2 enhances the anabolic metabolism of serotonin to $\mathrm{N}$-acetylserotonin (melatonin) and then to melatonin, the main sleep-regulating hormone and a powerful antioxidant [30], [31].

A study [32] reports on the antiviral activity of harmaline 2 against herpes 1 and 2 (HSV-1 and HSV-2) by inhibiting early transcription of the virus at a noncytotoxic concentration.

It is known that harmaline $\mathbf{2}$ acts as an inhibitor of histamine-N-methyltransferase. This explains how harmaline $\mathbf{2}$ has a stimulating effect on wakefulness.

Deoxypeganin 13 and peganin 3 are used as anticholinesterase drugs [30]. On the basis of deoxypeganin, the drug "Deoxypeganin hydrochloride" was created, which is used to treat lesions of the peripheral nervous system, Parkinson's disease, and the consequences of cerebrovascular accident. The drug helps to restore neuromuscular conduction, increases the tone of unstriated muscles. 
Peganin hydrochloride6 (in the form ofampoules and tablets) is approved as an anticholinesterase agent for myopia and myasthenia, and also as a laxative for constipation and intestinal atony of various origins. Harmine 1, contained in the seeds of $P$. harmala L., is recommended in the treatment of the consequences of epidemic encephalitis, tremor palsy and Parkinson's disease.

On the other hand, harmine 1 and its derivatives are considered as promising sources of neurotropic drugs. Harmine $\mathbf{1}$ has antidepressant, anxiolytic, behavioral, and antitumor potential, both in vitro and in vivo, and can also be used to treat the effects of epidemic encephalitis and Parkinson's disease [33].

Beta-carboline alkaloids exhibit a wide range of psychopharmacological effects by interacting with benzodiazepine, imidazoline, serotonin, and opiate receptors, as well as by inhibiting monoamine oxidase [34]. Neurochemical and behavioral studies have shown that beta-carboline alkaloids, harmine 1 and its derivatives, facilitate dopaminergic transmission and interact with dopaminergic $D_{1}$ and $D_{2}$ receptors in the corpus striatum [35]. It is known that the majority of betacarboline alkaloids are potent inhibitors that metabolize the neurotransmitters of catechol-amines [36]. Several potential molecular targets that were identified for the central pharmacological effects of harmine 1 include zinc-dependent CDK kinases (CDK1, 2, and 5), DYRK, MAO-A, 5- $\mathrm{HT}_{2 \mathrm{~A}}$ sites, and imidazoline receptors [37]. This alkaloid has antidepressant activity by interacting with MAO-A and several cell surface receptors, including the serotonin receptor $2 \mathrm{~A}$ (5-hydroxytritamine receptor $2 \mathrm{~A}, 5-\mathrm{HT}_{2 \mathrm{~A}}$ ), have the ability to stimulate the release of dopamine, justifying its use in the treatment of brain disorders [38].

In addition, it was reported that harmine 1 exhibits cytotoxic activity in relation to human tumor cell lines [39].

During the study of cytotoxic and genotoxic effects of harmine 1 on fibroblasts of the lung of the Chinese hamster V79 in vitro using single-stranded gel analysis, it was determined that at a dose of $40-50 \mu \mathrm{g} / \mathrm{ml}$, this alkaloid increases the frequency of aberrant cells and induces DNA damage [40]. Other authors [41] confirmed its ability to induce single or double DNA breaks. The cytotoxicity of harmine 1 was established on a shrimp lethality test and by microdilution to determine the minimum inhibitory concentration [42]. This indole alkaloid activates both internal and external pathways of apoptosis and regulates several transcription factors and pro-inflammatory cytokines, and reduces tumor capillary formation, showing an angiogenic inhibitory potential [43], [44]. It also inhibits the breast cancer resistance protein, which overexpresses MDA-MB-231 breast cancer cells [45]. Harmine 1 toxicity was assessed by cytochalasin-B-blocked micronucleus assay and viability of colony assay with four different human cells, including non-transformed CCD18Lu and transformed
HeLa, C33A, and SW480 cells [39]. Harmine 1 showed an inhibitory effect on cell proliferation against all human carcinoma cells, while in cytotoxicity assays, it showed a strong inhibitory effect on the growth and proliferation of carcinoma cells, while it did not significantly affect resting fibroblasts [46]. In other studies, harmine 1 has shown cytotoxicity against HL60 and K562 cell lines [47].

This indole alkaloid is a potent inhibitor of kinase 1A (Dyrk1A) involved in Down's syndrome and functions as an ATP-competitive inhibitor against Dyrk1A [48].

The results of a study of the comparative effectiveness of anti-venom for various psychoactive drugs indicated that harmine $\mathbf{1}$ is predominantly effective against various addictive substances (cocaine $>$ amphetamines $>$ nicotine) [49].

This alkaloid significantly increases the expression of the GLT-1 protein and significantly attenuates the expression levels of interleukin- $1 \beta$ and tumor- $\alpha$ necrosis factor, thereby weakening the apoptotic death of neurons in the hippocampus [50].

Rodent studies have shown that harmine 1 may also reduce brain infarction volume and neuronal cell death due to the activation of the glutamate 1 transporter, which reduces excessive and neurotoxic glutamate levels, suggesting that harmine 1 may also have neuroprotective properties. This alkaloid is a selective inhibitor of the protein kinase DYRK1A, a molecule essential for the development of the nervous system, and supports the survival of dopaminergic neurons in mice treated with 1-methyl-4-phenyl-1,2,3,6tetrahydropyridine (Parkinson's disease) [51], [52].

Harmine 1 interacts with the serotonin $2 \mathrm{~A}$ receptor and was shown to have an antidepressant effect in rodent models [53]. In addition, it increases brain-derived neurotrophic factor (BDNF) in the rat hippocampus. In humans, decreased BDNF levels are associated with major depression. In addition, MAO-A inhibitors reduce the breakdown of serotonin and norepinephrine and are used to treat depression [54].

Despite considerable evidence for antidepressant effects in animal models, harmine 1 has never been used as an antidepressant in humans. However, it was already mentioned in 1930 that it may be useful for patients with catatonic schizophrenia, and has recently been again suggested as a potential treatment option for psychosis.

Beta-carboline alkaloids inhibit monoamine oxidase, thereby exerting an antidepressant effect. Therefore, harmine 1 has neuroprotective activity, reduces oxidative stress in nervous tissue, increases BDNF, improves cognitive functions, and increases memory capacity [54].

Thus, harmine 1 has a neuroprotective effect, which is associated with the interaction of this alkaloid with serotonin and dopaminergic receptors $D_{1}$ and $D_{2}$, 
inhibition of monoamine oxidase. It shows cytotoxic activity against human tumor cells, while causing DNA break.

Considering that harmine 1 exhibits hallucinogenic and toxic properties in high doses, which are much higher than the usual clinical doses, we carried out a study of acute and chronic toxicity, determination of antidepressant, antiparkinsonian, antihypoxic, and anxiolytic activity, a study of the pharmacokinetics and bioavailability of harmine hydrochloride $\mathbf{5}$ in small doses, and molecular docking on biological targets.

\section{Pharmacological Study of Harmine Hydrochloride}

\section{Acute and chronic toxicity}

According to the results of the study of acute toxicity, it was established that harmine hydrochloride 5 belongs to the category of moderately toxic substances. $\mathrm{LD}_{50}$ of harmine hydrochloride $\mathbf{5}$ when administered intraperitoneally to laboratory rats is $87 \mathrm{mg} / \mathrm{kg}$. According to the classification of GOST 12.1.007-76, harmine hydrochloride when administered intragastrically to rats is moderately toxic (hazard Class II). Approximately, the same results were obtained in South America in the study of harmine 1, derived from the Ayahuasca plant, in the form of a slight decrease in the viability of the cell culture treated with a solution concentration of $10.5 \mu \mathrm{g} / \mathrm{ml}$ for $48 \mathrm{~h}$, but even showed some increase in the proliferation of nerve cells under in vitro exposure to primary alkaloids. According to the results of a study of chronic toxicity, harmine hydrochloride $\mathbf{5}$ showed that its administration in doses of $2.5 \mathrm{mg} / \mathrm{kg}, 5 \mathrm{mg} / \mathrm{kg}, 9 \mathrm{mg} / \mathrm{kg}$, and $10 \mathrm{mg} / \mathrm{kg}$ to laboratory rats for 3 months did not cause pathological changes in the general condition of the animals. Minor deviations in the functional state of internal organs and blood biochemical parameters were noted. It was established that harmine hydrochloride 5 does not have an allergenic, carcinogenic, and mutagenic effect, does not have immunotoxicity and reproductive toxicity.

\section{Study of the Pharmacokinetics of Harmine Hydrochloride}

In experiments on male Wistar rats ( $n=180$ ) using an Agilent 1260 high-performance liquid chromatography and an Agilent 6120 mass spectrometer, it was established that the time of the main elimination from the body after a single oral administration of harmine hydrochloride $\mathbf{5}$ does not exceed $24 \mathrm{~h}$. The residual concentration of the substance during this registration period was 3.11 $\pm 1.3 \mathrm{ng} / \mathrm{mL}$ for a dose of $4.5 \mathrm{mg} / \mathrm{kg}$ and $10.30 \pm$ $1.13 \mathrm{ng} / \mathrm{ml}-40 \mathrm{mg} / \mathrm{kg}$. The semiejection period of harmine hydrochloride 5 in the urine at a dose of $40 \mathrm{mg} / \mathrm{kg}$ was $3.00 \pm 0.8 \mathrm{~h}$, at a dose of $4.5 \mathrm{mg} / \mathrm{kg}-2.00$ $\pm 0.6 \mathrm{~h}$. The half-life of harmine hydrochloride 5 from the blood was $5.00 \pm 1 \mathrm{~h}(40 \mathrm{mg} / \mathrm{kg})$ and $4.00 \pm 0.1 \mathrm{~h}$ $(4.5 \mathrm{mg} / \mathrm{kg})$. In blood serum, the clearance of harmine hydrochloride 5 at a dose of $40 \mathrm{mg} / \mathrm{kg}$ was $63.40 \pm$ $15.9 \mathrm{l} / \mathrm{h}$, at a dose of $4.5 \mathrm{mg} / \mathrm{kg}-54.40 \pm 13.6 \mathrm{l} / \mathrm{h}$. With the administration of harmine hydrochloride $\mathbf{5}$, the quantitative content is quickly achieved and the concentration of the active substance in the blood significantly increases.

\section{Bioavailability}

The relative bioavailability of harmine hydrochloride $\mathbf{5}$ was studied at a dose of $50 \mathrm{mg}$ in 12 lagomorphic male chinchilla rabbits. It was established that harmine hydrochloride $\mathbf{5}$ has pharmacokinetic advantages, namely, a relatively rapid achievement of the maximum plasma concentration $\left(T_{\max }\right)$ and a significant increase in the concentration of the active substance in the blood, and at the same time, it was absorbed much faster when administered orally (per os). The relative bioavailability of harmine hydrochloride 5 is $112.7 \%$.

\section{Antidepressant Activity}

The antidepressant activity of harmine hydrochloride $\mathbf{5}$ was studied in vivo in the Porsolt's test (behavioral despair).

The stress state was induced in mice by forced swimming. The animals were placed in a cylinder $10 \mathrm{cmin}$ diameter and $25 \mathrm{cmin}$ height. The cylinder was filled $1 / 3$ with water $\left(27^{\circ} \mathrm{C}\right)$. After unsuccessful attempts to get out of the water, the animals assumed a characteristic motionless posture, which was regarded as the appearance of depression (despair). All active attempts of animals to get out of the water were recorded during the first $6 \mathrm{~min}$ after immersion into water. Behavioral indicators were as follows: The duration of the first act of motor activity, the time of active swimming, and the time of immobilization. The test subjects at a dose of $10 \mathrm{mg} / \mathrm{kg}$ were administered orally as a suspension in $1 \%$ starch mucilage intragastrically 1 hbefore the study. Control animals received an equal volume of starch mucilage. Reference drug "Amitriptyline" at a dose of $10 \mathrm{mg} / \mathrm{kg}$ was administered orally as a suspension in 
$1 \%$ starch mucilage intragastrically 1 hbefore the study (Table 1).

Table 1: Antidepressant activity of harmine hydrochloride

\begin{tabular}{|c|c|c|c|c|}
\hline Name of substance, dose & & $\begin{array}{l}\text { Duration of } \\
\text { the first act of } \\
\text { motor activity } \\
\text { (sec) }\end{array}$ & $\begin{array}{l}\text { Active } \\
\text { swimming } \\
\text { time (sec) }\end{array}$ & $\begin{array}{l}\text { Immobilization } \\
\text { time (sec) }\end{array}$ \\
\hline Control & & $53.0 \pm 20.7$ & $269.6 \pm 26.3$ & $90.4 \pm 26.3$ \\
\hline Reference drug "Amitriptyline" & $10 \mathrm{mg} / \mathrm{kg}$ & $64.4 \pm 24.9$ & $328.2 \pm 14.1^{*}$ & $31.8 \pm 14.1^{*}$ \\
\hline Harmine hydrochloride 5 & $10 \mathrm{mg} / \mathrm{kg}$ & $78.4 \pm 13.9$ & $320.8 \pm 36.3^{*}$ & $43.2 \pm 37.5$ \\
\hline
\end{tabular}

It was established that in the Porsolt's test, harmine hydrochloride $\mathbf{5}$ exhibited a pronounced antidepressant effect. Hence, under the action of harmine hydrochloride 5 at a dose of $10 \mathrm{mg} / \mathrm{kg}$, a significant increase in the duration of active swimming was observed by 1.2 times, and there was also a decrease in the immobilization time by 2.1 times, compared with the control group.

\section{Antiparkinsonian Activity}

The antiparkinsonian activity of harmine hydrochloride $\mathbf{5}$ was determined in models of haloperidol catalepsy and 1-methyl-4-phenyl-1,2,3,6tetrahydropyridine-induced parkinsonian syndrome in mice compared with levodopa, a reference antiparkinsonian drug, and placebo-control. In the haloperidol catalepsy model, harmine hydrochloride $\mathbf{5}$ at a dose of $2.5 \mathrm{mg} / \mathrm{kg}$ showed an efficacy comparable to levodopa at a dose of $50 \mathrm{mg} / \mathrm{kg}$ and a 3-fold decrease in the level of catalepsy in the "Stride Length Test," "vertical pole," and "rotating pole" tests.

On the model of 1-methyl-4-phenyl-1,2,3,6tetrahydropyridine-induced parkinsonian syndrome, the assessment of rigidity by change in stride length showed results in the groups of harmine hydrochloride $\mathbf{5}$ at a dose of $2.5 \mathrm{mg} / \mathrm{kg}$ and levodopa $50 \mathrm{mg} / \mathrm{kg}$, comparable to the intact group and superior to the control group without therapy. The assessment of oligokinesia in the open field test in the groups of harmine hydrochloride 5 and levodopa gave comparable results. Motor deficit in the "vertical pole" test in the early stages regressed in the group receiving harmine hydrochloride 5 at a dose of $5 \mathrm{mg} / \mathrm{kg}$ and was comparable to the group receiving levodopa at a dose of $100 \mathrm{mg} / \mathrm{kg}$. Evaluation of movements coordination in the "rotating pole" test in the groups of harmine hydrochloride $\mathbf{5}$ and levodopa showed a result that exceeded the control group by 2.1 times with the preliminary administration of harmine hydrochloride 5 at a dose of $5 \mathrm{mg} / \mathrm{kg}$ and levodopa $50 \mathrm{mg} / \mathrm{kg}$, comparable to each other. In the study, an antiparkinsonian effect of harmine hydrochloride 5 was confirmed, comparable to levodopa based on the results of assessing the severity of rigidity, oligokinesia, motor, and coordination disorders. Comparative analysis of the data obtained in the experiment on C57BI/6 mice in three doses $(2.5,5.0$, and $10.0 \mathrm{mg} / \mathrm{kg})$, ranging from 0.1 to $0.001 L_{50}$ on the effects of acute and subchronic systemic administration of harmine hydrochloride $\mathbf{5}$, made it possible to confirm the presence of psychotropic effects of the activating type of harmine hydrochloride.

\section{Antihypoxic Activity}

The antihypoxic effect of harmine hydrochloride $\mathbf{5}$ was studied in hypobaric hypoxia and normobaric hypoxia with hypercapnia in a hermetic volume on outbred male rats. The model of hypoxia with hypercapnia in the hermetic volume was carried out according to the standard protocol [55]. The mice were placed in a sealed $190 \mathrm{ml}$ glass container. The lifespan of the animals was assessed in relation to the control. The difference in the weight of the animals did not exceed 2-3 g.

Harmine hydrochloride 5 at a dose of $2.5 \mathrm{mg} / \mathrm{kg}$ and at a dose of $5 \mathrm{mg} / \mathrm{kg}$ increased the lifespan of animals by 2.48 and 2.4 times, respectively, relative to the reference drug "Mexidol." Under the influence of harmine hydrochloride $\mathbf{5}$, the number of animals also increased, the latent time of death of which was 2 or more times higher than the latent time of death in the corresponding control (equal to an average of $100 \mathrm{~s}$ ). The revealed antihypoxic effect of harmine hydrochloride 5 in small doses is comparable to the effect of "Mexidol" at a dose of $100 \mathrm{mg} / \mathrm{kg}$ and exceeded the activity of "Mexidol" when used at a dose of $200 \mathrm{mg} / \mathrm{kg}$. Harmine hydrochloride 5 at doses of $2.5 \mathrm{mg} / \mathrm{kg}$ and $5 \mathrm{mg} / \mathrm{kg}$ has antihypoxic activity in the test of hypobaric hypoxia, comparable to the activity of "Mexidol" at a dose of $100 \mathrm{mg} / \mathrm{kg}$.

\section{Anxiolytic (anti-anxiety) Action}

The anxiolytic activity of harmine hydrochloride 5 was studied in the "elevated plus maze" test. The method of studying anxiolytic activity in the "elevated plus maze" test is based on the natural preference of dark holes by rodents, as well as on the fear of being in open areas and falling from a height. The animals were placed in an elevated plus maze and the following indicators of anxiolytic activity were recorded for $3 \mathrm{~min}$ : Latent time of exit into the open sleeve (s), the number of exits into the open sleeve, and the total time spent in the open sleeves of the maze (s).

One of the most significant evaluation criteria in the study of anxiolytic activity in the elevated plus maze was the time spent by animals in the open sleeve, which indicates the presence or absence of natural 
phobias, open and illuminated spaces in laboratory animals.

With the administration of harmine hydrochloride $\mathbf{5}$, the manifestation of anxiety in animals decreased. Hence, the time spent by animals in open sleeves in the group with the use of harmine hydrochloride 5 was $18.8 \pm 8.5 \mathrm{~s}$ and exceeded the showings of group of reference drug amitriptyline $(5.5 \pm 6.0 \mathrm{~s})$. The number of entries into the open sleeves in the harmine hydrochloride $\mathbf{5}$ group was comparable to the comparison group - amitriptyline.

The showings of the number of overhangs in the group with the administration of harmine hydrochloride $\mathbf{5}$ were higher than the control group and are comparable with the data of the comparison group. The number of standings in animals in the group with harmine hydrochloride $\mathbf{5}$ was the same as in the comparison group (Table 2).

Table 2: Influence of the studied compounds on the behavior of rats in the "elevated plus maze" test

\begin{tabular}{|c|c|c|c|c|c|}
\hline Group & $\begin{array}{l}\text { Time spent } \\
\text { in a closed } \\
\text { sleeve, } \\
(\mathrm{sec})\end{array}$ & $\begin{array}{l}\text { Time spent } \\
\text { in the open } \\
\text { sleeve, } \\
\text { (sec) }\end{array}$ & $\begin{array}{l}\text { Number of } \\
\text { entries into } \\
\text { open sleeves, } \\
\text { (times) }\end{array}$ & $\begin{array}{l}\text { Number } \\
\text { of entries } \\
\text { into closed } \\
\text { sleeves, } \\
\text { (times) }\end{array}$ & $\begin{array}{l}\text { Number of } \\
\text { hangings, } \\
\text { (times) }\end{array}$ \\
\hline Intact rats & $113.8 \pm 23.9$ & $9.7 \pm 16.0$ & $0.8 \pm 0.4$ & $4.0 \pm 2.4$ & $3.8 \pm 4.7$ \\
\hline $\begin{array}{l}\text { Control (without } \\
\text { treatment) }\end{array}$ & $\begin{array}{l}131.2 \pm \\
35.3\end{array}$ & $8.0 \pm 9.8$ & $0.5 \pm 0.5$ & $4.2 \pm 1.7$ & $5.0 \pm 1.6$ \\
\hline $\begin{array}{l}\text { Reference group } \\
\text { Amitriptyline }-10 \\
\mathrm{mg} / \mathrm{kg}\end{array}$ & $\begin{array}{l}133.8 \pm \\
16.9\end{array}$ & $16.0 \pm 4.5$ & $0.8 \pm 1.0$ & $3.8 \pm 1.5$ & $2.8 \pm 1.2^{*}$ \\
\hline $\begin{array}{l}\text { Harmine hydrochloride } \\
5-10 \mathrm{mg} / \mathrm{kg}\end{array}$ & $\begin{array}{l}120.0 \pm \\
18.5\end{array}$ & $18.8 \pm 8.5$ & $1.3 \pm 0.5$ & $2.2 \pm 0.4^{*}$ & $\begin{array}{l}10.0 \pm \\
2.3^{*}\end{array}$ \\
\hline
\end{tabular}

Thus, harmine hydrochloride $\mathbf{5}$ reduced feelings of fear and anxiety in animals, not inferior in the level of manifestation of anti-anxiety action to the reference drug amitriptyline.

\section{Molecular Docking of Harmine Hydrochloride}

Molecular docking of harmine hydrochloride $\mathbf{5}$ was carried out on biological targets: Serotonin $5-\mathrm{HT}_{2 \mathrm{C}}$ receptor, dopamine $\mathrm{D}_{2}$ receptor, and monoamine oxidase using the Maestro graphical interface of the Schrödinger Suite software package (Schrödinger, LLC, New York, NY, 2017). The docking mode was SP (standard precision). As the final results, we used the value of the scoring function G-Score, which shows the energy and strength of binding of the ligand to the target molecule (Table 3).

Table 3: Binding energies of harmine hydrochloride with serotonin $5-\mathrm{HT}_{2 \mathrm{C}}$ receptor, dopamine $\mathrm{D}_{2}$ receptor, and with monoamine oxidases $A$ and $B$

\begin{tabular}{lllll}
\hline Compound & $\begin{array}{l}\text { Serotonin } \\
\text { 5- } \mathrm{HT}_{2 \mathrm{C}} \text { receptor }\end{array}$ & $\begin{array}{l}\text { Dopamine } \\
\mathrm{D}_{2} \text { receptor }\end{array}$ & $\begin{array}{l}\text { Monoamine } \\
\text { oxidase A (MAO-A) }\end{array}$ & $\begin{array}{l}\text { Monoamine } \\
\text { oxidase B (MAO-B) }\end{array}$ \\
\hline $\begin{array}{l}\text { Harmine } \\
\text { hydrochloride } 5\end{array}$ & -6.199 & -5.366 & -7.503 & -7.145 \\
\hline
\end{tabular}

As a result of the molecular docking of harmine hydrochloride $\mathbf{5}$, it showed the best binding energies with monoamine oxidases $A$ and $B$ (-7.503 and $-7.145 \mathrm{kcal} / \mathrm{mol}$, respectively). Harmine hydrochloride 5 showed a relatively strong bond with the serotonin $5-\mathrm{HT}_{2 \mathrm{C}}$ receptor and the dopamine $\mathrm{D}_{2}$ receptor $(-6.199$ and $-5.366 \mathrm{kcal} / \mathrm{mol}$, respectively) (Figures 3-6).

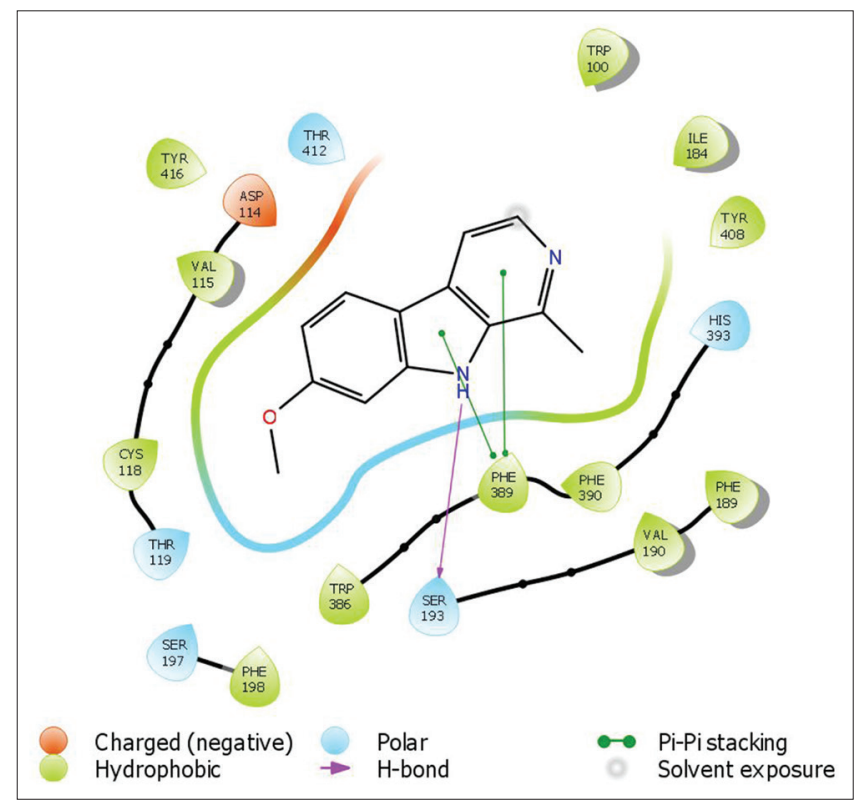

Figure 3: Interaction of dopamine $D_{2}$ receptor with harmine hydrochloride

The results of molecular docking indicated the presence of strong bonds in the studied harmine hydrochloride $\mathbf{5}$ with serotonin receptor $5-\mathrm{HT}_{2 \mathrm{C}}(-6.199 \mathrm{kcal} / \mathrm{mol})$, dopamine receptor $\mathrm{D}_{2}$ $(-5.544 \mathrm{kcal} / \mathrm{mol})$, as well as monoamine oxidase A and B (-7.510 and $-7.395 \mathrm{kcal} / \mathrm{mol}$, respectively), suggest that the mechanism of the antidepressant action of harmine hydrochloride $\mathbf{5}$ is realized at the level of synoptic neurotransmission. The obtained docking data were confirmed by the results of experimental studies of harmine hydrochloride $\mathbf{5}$ in vivo using the Porsolt's

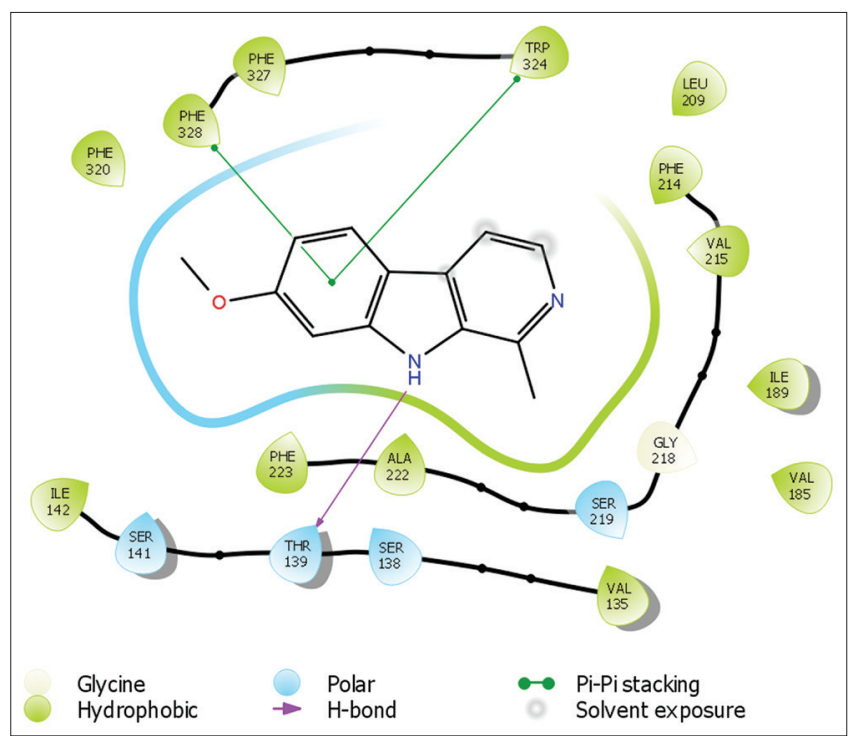

Figure 4: Interaction of the $5-H T_{2 C}$ serotonin receptor with harmine hydrochloride 


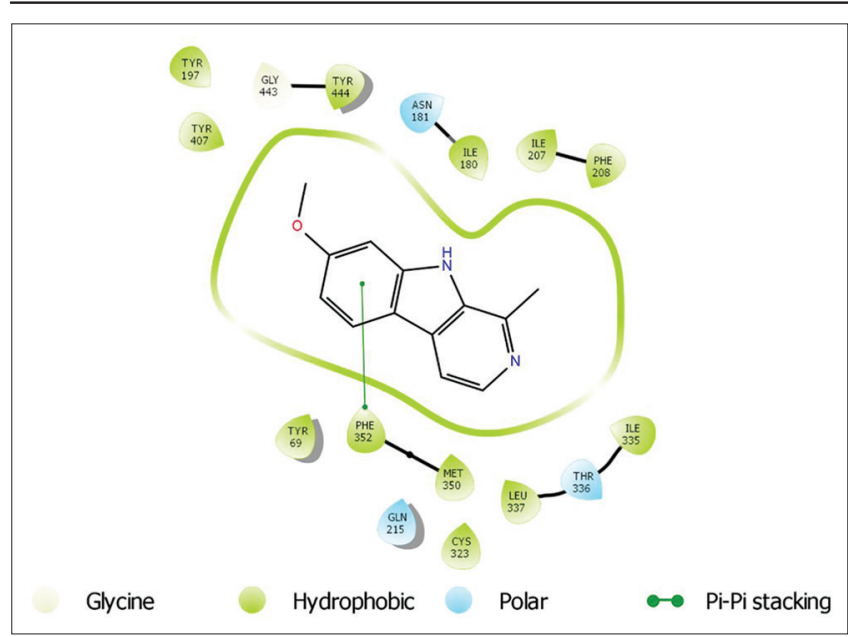

Figure 5: Interaction of monoamine oxidase $A$ with harmine hydrochloride

test (behavioral despair), as well as in vivo experiments with induced parkinsonian syndrome.

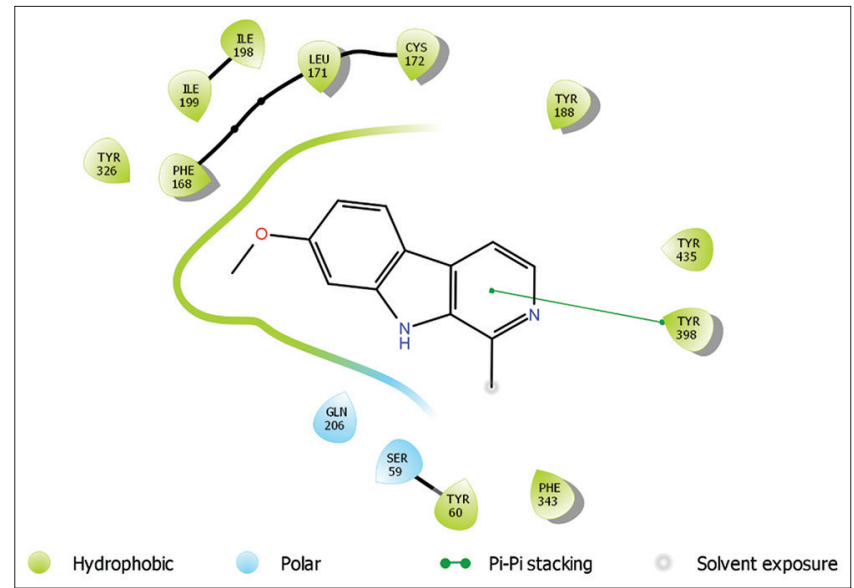

Figure 6: Interaction of monoamine oxidase $B$ with harmine hydrochloride

\section{Conclusions}

The alkaloids of $P$. harmala $L$. are potential sources of original drugs. First of all, beta-carboline alkaloids have neurotropic activity, since they interact with monoamine oxidase $A$ and serotonin $2 A$ receptor (5-hydroxytritamine receptor $2 \mathrm{~A}, 5-\mathrm{HT}_{2} \mathrm{~A}$ ) and dopamine $D_{2}$ receptor. Among them, harmine 1 is especially distinguished by its neurotropic action.

The data of preclinical studies presented by us showed that harmine hydrochloride $\mathbf{5}$ has antidepressant, antihypoxic, and antiparkinsonian effects, eliminates catalepsy caused by haloperidol in rats, and reduces oligokinesia and rigidity in the parkinsonian syndrome test.

In terms of antiparkinsonian effect, harmine hydrochloride $\mathbf{5}$ is not inferior to amitriptyline. The study of the relative bioavailability of harmine hydrochloride $\mathbf{5}$ in experimental animals showed that harmine hydrochloride $\mathbf{5}$ is absorbed much faster when administered orally, quickly reaching the highest concentration in blood plasma. At the same time, it reduces the level of cortisol in the experiment of stressinduced disorder.

And also as a result of chronic toxicity, it was established that harmine hydrochloride $\mathbf{5}$ does not have an allergenic, carcinogenic, and mutagenic effect, and does not have immunotoxicity and reproductive toxicity.

Thus, on the basis of the studies carried out, harmine hydrochloride 5 should be considered as a potential substance for the development of an original neurotropic drug.

\section{References}

1. Shahrajabian $M H$, Sun $W$, Cheng Q.A review of ginseng species in different regions as a multipurpose herb in traditional Chinese medicine, modern herbology and pharmacological science.J Med Plants Res. 2019;13(10):213-26.

2. Sun $W$, Shahrajabian $M H$, Khoshkharam M, Cheng $Q$. Adaptation of acupuncture and traditional Chinese herbal medicines because of climate change.J Stress Physiol Biochem. 202;16(1):85-90. https://doi.org/10.5530/pc.2020.1.10

3. Adekenov SM, Baitulin IO, Egeubayeva RA, Saparbayeva NA The current state of natural thickets of Peganum harmala $\mathrm{L}$. on the territory of South Kazakhstan. News NAS RK Biol Ser 2010;5:55-61.

4. Mashreghi M, Niknia S. The effect of Peganum harmala L. and Teucrium polium alcoholic extracts on growth of Escherichia coli 0157. Jundishapur J Microbiol. 2012;5(3):511-5. https://doi. org/10.5812/jjm.3665

5. Ababou A, Chouieb M, Bouthiba A, Saidi D, Hamedi Bouzina MM, Mederbal K. Spatial pattern analysis of Peganum harmala L. on the salted lower Chelif plain, Algeria. Turk J Bot. 2013;37:11121. https://doi.org/10.17129/botsci.2303

6. Astulla A, Zaima $\mathrm{K}$, Matsuno $\mathrm{Y}$, Hirasawa $\mathrm{Y}$, Ekasari $\mathrm{W}$, Widyawaruyanti $A$, et al. Alkaloids from the seeds of Peganum harmala showing antiplasmodial and vasorelaxant activities.J Nat Med. 2008;62(2):470-2. https://doi.org/10.1007/ s11418-008-0259-7 PMid: 18523842

7. Berrougui $\mathrm{H}$, Lopez-Lazaro M, Martin-Cordero C, Mamouchi M, Ettaib A, Herrera MD. Cytotoxic activity of methanolic extract and two alkaloids extracted from seeds of Peganum harmala L.J Natl Remedies. 2005;5:41-5.

8. Goel N, Singh N, Saini R. Efficient in vitro multiplication of Srian Rue (Peganum harmala L.) using 6-benzylaminopurine preconditioned seedling explants. Nat Sci. 2009;7:129-34.

9. Nafisi S, Asghari MH, Nezhadi MA, Ekhtiari MS. Possible antidiabetic effect Peganum harmala of streptozocine-induced mouse. World Appl Sci J. 2011;14(4):822-4

10. Darabpour E, Bavi AP, Motamedi H, Nejad SM. Antibacterial activity of different parts of Peganum harmala L. growing in Iran against multi-drug resistant bacteria. Excl J. 2011;10:252-263. PMid:29033706

11. Diba K, Shoar MG, Shabathkhori M, Khorshivand Z. Antifungal 
activity of alcoholic extract of Peganum harmala seeds.J Med Plants Res. 2011;5(23):5550-4

12. Mahmoudian M, Jalipour $\mathrm{H}$, Salehian P. Toxicity of Peganum harmala: Review and a case report. Iran J Pharmacol Ther 2002;1:1-4

13. Massoud $M$, Jalilpour $H$, Salehian P. Toxicity of Peganum harmala L.: Review and a case report. Iran J Pharmacol Ther. 2002;1:1-4.

14. Asgarpanah J, Ramezanloo F. Chemistry, pharmacology and medicinal properties of Peganum harmala L. Afr J Pharm Pharmacol. 2012;6(22):1573-80. https://doi.org/10.5897/ ajpp11.876

15. Patel K, Gadewar M, Tripathi R.A review on medicinal importance, pharmacological activity and bioanalytical aspects of betacarboline alkaloid "Harmine". Asian Pac J Trop Biomed. 2012;2(8):660-4. https://doi.org/10.1016/ s2221-1691(12)60116-6

PMid:23569990

16. Gammerman AF, Kadaev GN, Yatsenko-Khmelevsky AA Medicinal Plants. Moscow: Healing Plants, Higher School; 1990. p. 544

17. Movafeghi A, Abedini M, Fathiazad F, Aliasgharpour M, Omidi Y Floral nectar composition of Peganumharmala L. Nat Prod Res. 2009;23:301-8. https://doi.org/10.1080/14786410802076291 PMid:19235031

18. Faridi P, Younes G, Mohagheghzadeh A. Chemical composition of Peganum harmala L. smoke and volatile oil.J Essent Oil Bearing Plants. 2013;16(6):850-4. https://doi.org/10.1080/0972 060x.2013.861993

19. Khan AM, Qureshi RA, Ullah F, Gilani SA, Nosheen S, Sahreen MK, et al. Phytochemical analysis of selected medicinal plants of Margalla Hills and surroundings.J Med Plants Res. 2011;5(25):6017-23.

20. Kartal M, Altun ML, Kurucu S. HPLC method for the analysis of harmol, harmalole, harmine and harmaline in the seeds of Peganum harmala L.J Pharm Biomed 2003;311:263-9. https:// doi.org/10.1016/s0731-7085(02)00568-x PMid:12609665

21. Fatma B, Fatiha $M$, Noureddine D. Phytochemical and antimicrobial study of the seeds and leaves of Peganum harmala L. against urinary tract infection pathogens. Asian Pac J Trop Dis. 2016;6(10):822-6. https://doi.org/10.1016/ s2222-1808(16)61139-8

22. Siddiqui S, Khan OY, Faizi S, Shaheen B. Studies on the chemical constituents of the seeds of Peganum harmala: Isolation and structure elucidation of two $\beta$-carboline lactams-harmalanine and harmalacidine. Heterocycles. 1987;26(6):1401-20. https:// doi.org/10.3987/com-88-4490

23. Manske $F$, Perkin $V$, Robinson $R$. Harmine and harmaline. Part IX. Synthesis of harmaline.J Chem Soc. 1927;1(14):20-8. https://doi.org/10.1039/jr9270000001

24. Schults EE, Nurmaganbetov ZS, Turmukhanbetov AZ, Adekenov SM. Chemistry, pharmacology, and medical aspects of the plant Peganum harmala L. Pharmaceutical Bulletin. 2014;3:66-76. https//doi.org/10.5897/AJPP11.876

25. Chen Q, Chao RH, Chen HS, Hou X, Yan H, Zhou S, et al. Antitumor and neurotoxic effects of novel harmine derivatives and structure-activity relationship analysis. Int $\mathrm{J}$ Cancer. 2015;114(5):675-82. https://doi.org/10.1002/ijc.20703

26. Vachnadze VY, Suladze TS, Vachnadze NS, Kintsurashvili LG, Novikova ZN. Alkaloids of Peganum harmala L. and their biological activity. Georgian Med News. 2015;6:79-81. PMid:26087737

27. Réus GZ, Stringari RB, de Souza B, Petronilho F, Dal-Pizzol F. Harmine and imipramine promote antioxidant activities in prefrontal cortex and hippocampus. Oxid Med Cell Longev.
2010;3(5):325-31. https://doi.org/10.4161/oxim.3.5.13109 PMid:21150338

28. Serrano-Duenas M, Cardoso-Pelaez F, Sanchez-Ramos J. Effects of Banisteriopsis caapi extract on Parkinson's disease. Sci Rev Altern Med. 2001;5(3):127-32.

29. Yarnell E, Abascal K. Botanical treatments for depression: Part 2-herbal correctives for systemic imbalances. Altern Complement Ther. 2001;7(3):138-43. https://doi. org/10.1089/10762800151125056

30. Zheng XY, Zhang ZJ, Chou GX, Wu T, Cheng XM, Wang CH. Acetylcholinesterase inhibitive activity-guided isolation of two new alkaloids from seeds of Peganum nigellastrum Bunge by an in vitro TLC-bioautographic assay. Arch Pharm Res. 2009;32:1245-51. https://doi.org/10.1007/s12272-009-1910-x

31. Schwarz MJ, HoughtonPJ.Activities of extract and constituents of Banisteriopsis caapi relevant to parkinsonism. Pharmacol Biochem Behav. 2003;75(3):627-33. https://doi.org/10.1016/ s0091-3057(03)00129-1 PMid: 12895680

32. Paromita B, Durbadal O, Hemanta M.A dihydro-pyrido-indole potently inhibits HSV-1 infection by interfering the viral immediate early transcriptional events. Antiv Res. 2014;105(1):126-34. https://doi.org/10.1016/j.antiviral.2014.02.007

33. Blesa J, Przedborski S. Parkinson's disease: Animal models and dopaminergic cell vulnerability. Front Neuroanat. 2014;8:112. https://doi.org/10.3389/fnana.2014.00155 PMid:25565980

34. Tolkachev ON, Tolkachev VN, Sheichenko OP, Fateeva TV, Semenov AV, Abizov EA. Plant preparations based on indole alkaloids: Biological activity. Biol Med Pharm Chem Issues. 2018;9:3-14. https://doi.org/10.29296/25877313-2018-09-01

35. Farzin D, Haghparast A, Motaman S, Baryar F, Mansouri N. Effects of harmane and other $\beta$-carbolines on apomorphineinduced licking behavior in rat. Pharmacol Biochem Behav. 2011;98(2):215-9. https://doi.org/10.1016/j.pbb.2011.01.001 PMid: 21237191

36. Yonezawa $\mathrm{T}$, Hasegawa $\mathrm{S}$, Asai $\mathrm{M}$, Ninomiya $\mathrm{T}$, Sasaki $\mathrm{T}$, Cha BY, et al. Harmine, a $\beta$-carboline alkaloid, inhibits osteoclast differentiation and bone resorptionin vitroandin vivo. Eur J Pharmacol.2011;650(2-3):511-8. https://doi.org/10.1016/j. ejphar.2010.10.048

PMid:21047508

37. Egusa H, Doi M, Saeki M, Fukuyasu S, Akashi Y, Yokota $Y$ et al. The small molecule harmine regulates NFATc1 and Id2 expression in osteoclast progenitor cells. Bone. 2011;49(2):264-74. https://doi.org/10.1016/j.bone.2011.04.003 PMid:21504804

38. Iurlo $M$, Leone $M$, Schilström $B$, Linnér $L$, Nomikos $L$, Hertel $P$, et al. Effects of harmine on dopamine output and metabolism in rat striatum: Role of monoamine oxidase-a inhibition. Psychopharmacology.2001;159(1):98-104. https://doi. org/10.1007/s002130100879 PMid: 11797076

39. Jiménez J, Riverón-Negrete L, Abdullaev F, Espinosa-Aguirre J, Rodríguez-Arnaiz R. Cytotoxicity of the $\beta$-carboline alkaloids harmine and harmaline in human cell assays in vitro. Exp Toxicol Pathol. 2008;60(4-5):381-9.https://doi.org/10.1016/j. etp.2007.12.003

PMid:18430551

40. Boeira JM, da Silva J, Erdtmann B, Henriques JA. Genotoxic effects of the alkaloids harman and harmine assessed by comet assay and chromosome aberration test in mammalian cells in vitro. Pharmacol Toxicol. 2001;89(6):287-94. https://doi. org/10.1034/j.1600-0773.2001.d01-162.x

41. Boeira JM, Viana AF, Picada JN, Henriques JA. Genotoxic 
and recombinogenic activities of the two beta-carboline alkaloids harman and harmine in Saccharomyces cerevisiae. Mutat Res. 2002;500(1-2):39-48. https://doi.org/10.1016/ s0027-5107(01)00294-9

PMid: 11890933

42. Reza VR, Abbas H. Cytotoxicity and antimicrobial activity of harman alkaloids.J Pharmacol Toxicol. 2007;2(7):677-80. https// doi.org/10.3109/13880209.2010.519390

43. Hamsa TP, Kuttan G. Harmine activates intrinsic and extrinsic pathways of apoptosis in B16F-10 melanoma. Chin Med. 2011;6(1):11. https://doi.org/10.1186/1749-8546-6-11 PMid:21429205

44. Hamsa TP, Kuttan G. Harmine inhibits tumour specific neovessel formation by regulating VEGF, MMP, TIMP and pro-inflammatory mediators both in vivo and in vitro. Eur $\mathrm{J}$ Pharmacol. 2010;649(1-3):64-73. https://doi.org/10.1016/j. ejphar.2010.09.010

45. Ma $Y$, Wink $M$. The beta-carboline alkaloid harmine inhibits BCRP and can reverse resistance to the anticancer drugs mitoxantrone and camptothecin in breast cancer cells. Phytother Res. 2010;24(1):146-9. https://doi.org/10.1002/ptr.2860 PMid:19548284

46. Song Y, Kesuma D, Wang J, Deng Y, Duan J, Wang JH, et al. Specific inhibition of cyclin-dependent kinases and cell proliferation by harmine.Biochem Biophys Res Commun.2004;317(1):128-32. https://doi.org/10.1016/j. bbrc.2004.03.019

PMid:15047157

47. Jahaniani F, Ebrahimi SA, Rahbar-Roshandel N, Mahmoudian M. Xanthomicrol is the main cytotoxic component of Dracocephalum kotschyiiand a potential anti-cancer agent. Phytochemistry.2005;66(13):1581-92. https://doi.org/10.1016/j. phytochem.2005.04.035 PMid:15949825

48. Adayev T, Wegiel J, Hwanga YW. Harmine is an ATP-competitive inhibitor for dual-specificity tyrosine phosphorylation-regulated kinase 1A (Dyrk1A). Arch Biochem Biophys. 2011;507(2):212-8. https://doi.org/10.1016/j.abb.2010.12.024

\section{PMid:21185805}

49. Owaisat S, Robert B, Scott M. In vivo comparison of harmine efficacy against psychostimulants: Preferential inhibition of the cocaine response through a glutamatergic mechanism. Neurosci Lett. 2012;525(1):12-6. https://doi.org/10.1016/j. neulet.2012.07.052

PMid:22877698

50. Zhong Z, Tao Y. Treatment with harmine ameliorates functional impairment and neuronal death following traumatic brain injury. Mol Med Rep. 2015;12(6):7985-91. https://doi.org/10.3892/ mmr.2015.4437

51. Mennenga SE, Gerson JE, Dunckley T, Bimonte-Nelson HA Harmine treatment improves short-term memory in older rats: Dissociation of cognition and the ability to meet the procedural requirements of maze testing. Physiol Behav. 2015;138:260-5. https://doi.org/10.1016/j.physbeh.2014.09.001 PMid:25250831

52. Becker V, Sipple V. Activation, regulation, and inhibition DYRK1A. FEBS J. 2011;278:246-56. https://doi. org/10.1111/j.1742-4658.2010.07956.x PMid:21126318

53. Fortunato JJ, Réus GZ, Kirsch TR,Stringari RB, Stertz L, Kapczinski $F$, et al. Acute harmine administration induces antidepressive-like effects and increases BDNF levels in the rat hippocampus. Prog Neuropsychopharmacol Biol Psychiatry. 2009;33(8):1425-30. https://doi.org/10.1016/j. pnpbp.2009.07.021

PMid:19632287

54. Fortunato JJ, Réus GZ, Kirsch TR,Stringari RB, Fries GR, Kapczinski F, et al. Chronic administration of harmine elicits antidepressant-like effects and increases BDNF levels in rat hippocampus.J Neural Transm. 2010;117:1131-7. https://doi. org/10.1007/s00702-010-0451-2

PMid:20686906

55. Voronina TA, Ostrovskaya TA. In: Khabriev RN, editor. Guidelines for Experimental (Preclinical) Study of New Pharmacological Substances. Moscow: Food and Drug Administration; 2005. p. 308-20. 